\title{
BPA toxicity during development of zebrafish embryo
}

\author{
C. F. V. Scopel ${ }^{a}$ (D), C. Sousa ${ }^{b}$ (D), M. R. F. Machado ${ }^{c}$ (D) and \\ W. G. Dos Santos ${ }^{a *}$ (i) \\ aPrograma de Pós-graduação em Ciências Aplicadas à Saúde, Laboratório de Genética e Biologia Molecular, Universidade \\ Federal de Goiás - UFG, Regional Jataí, Campus Jatobá, Rodovia BR 364, Km 195, Setor Industrial, CEP 75801-615, \\ Jataí, GO, Brasil \\ bUnidade Acadêmica Especial de Ciências Biológicas, Universidade Federal de Goiás - UFG, Regional Jataí, Campus \\ Jatobá, Rodovia BR 364, Km 195, Setor Industrial, CEP 75801-615, Jataí, GO, Brasil \\ 'Programa de Pós-graduação em Biociência Animal, Universidade Federal de Goiás - UFG, Regional Jataí, Campus \\ Jatobá, Rodovia BR 364, Km 195, Setor Industrial, CEP 75801-615, Jataí, GO, Brasil \\ *e-mail: wagner_santos@ufg.br
}

Received: 30 October 2019 - Accepted: December 23, 2019 - Distributed: May 31, 2021

(With 7 figures)

\begin{abstract}
Bisphenol A (BPA) is a monomer used in the production of polycarbonate, a polymer commonly found in plastics, epoxy resins and thermal papers. The presence of BPA in food, water, air and dust has been of great concern in recent years not only due to environmental and ecological issues but also because of its supposed risk to public health related to its mutagenic and carcinogenic potential. In this study we evaluated the toxicity of bisphenol A in zebrafish embryos (Danio rerio) and determined the $50 \%$ lethal concentration $\left(\mathrm{LC}_{50}\right)$ of this chemical. BPA was used at concentrations ranging from $1 \mu \mathrm{M}$ to $100 \mu \mathrm{M}$ in E3 medium/0.5\% dimethylsulfoxide (DMSO) from previously prepared stock solutions in $100 \%$ DMSO. Controls included embryos exposed only to E3 medium or supplemented with $0.5 \%$ DMSO. Camptothecin (CPT), a known inhibitor of cell proliferation was used as positive control at a concentration of $0.001 \mu \mathrm{M}$ in E3 medium/0.5\% DMSO. Adults zebrafish were placed for breeding a day before the experimental set up, then, viable embryos were collected and selected for use. Experiments were carried out in triplicates, according to specifications from Organization for Economic Cooperation and Development (OECD). One embryo/well (25 embryos per concentration) was distributed in 96 well microplates in presence or absence of the chemicals. The plates were kept in BOD incubators with a controlled temperature of $28.5^{\circ} \mathrm{C}$ and with photoperiod of $14 \mathrm{~h} \mathrm{light:10} \mathrm{h} \mathrm{dark.} \mathrm{After} 24 \mathrm{~h}$, 48h, 72h and 96h exposure, the exposed embryos were evaluated according to the following parameters: mortality, coagulation, rate of heartbeat, hatching and presence of morphological abnormalities. Photography was obtained by photomicroscopy. Apoptosis was evaluated by DNA ladder assay. DNA was extracted by phenol:chloroform method and analyzed by $2 \%$ agarose gel electrophoresis. DNA fragments were visualized after ethidium bromide staining in ultraviolet transilluminator. The $\mathrm{LC}_{50}$ determined for BPA was $70 \mu \mathrm{M}$ after 24 hours, $72 \mu \mathrm{M}$ after 48 hours, $47 \mu \mathrm{M}$ after 72 hours and $31 \mu \mathrm{M}$ after 96 hours exposure. BPA induced morphological and physiological alterations such as yolk sac and pericardial edema, hatching delay or inhibition, spine deformation, decreasing in heartbeat rate and mortality. In conclusion, this study demonstrated that BPA induced marked malformations in zebrafish embryos at concentrations above $25 \mu \mathrm{M}$ corroborating the current concerns related to the widespread presence of BPA in the air, food and water used by humans as well as in the bodily fluids and tissues.
\end{abstract}

Keywords: bisphenol, toxicity, embryogenesis.

\section{Toxicidade do BPA durante o desenvolvimento de embriões de Zebrafish}

\section{Resumo}

Bisfenol A (BPA) é um monômero utilizado na produção de policarbonato, um polímero comumente encontrado em plásticos, resinas epóxi e papéis térmicos. A presença de BPA em alimentos, água, ar e poeira tem sido motivo de grande preocupação nos últimos anos, não só devido a questões ambientais e ecológicas, mas também ao suposto risco para a saúde pública relacionado ao seu potencial mutagênico e carcinogênico. Neste estudo avaliamos a toxicidade do bisfenol A em embriões de peixe-zebra (Danio rerio) e determinamos a concentração letal $50 \%\left(\mathrm{LC}_{50}\right)$ deste composto químico. O BPA foi usado na faixa de concentração entre $1 \mu \mathrm{M}$ e $100 \mu \mathrm{M}$ em meio E3/0,5\% de dimetilsulfóxido (DMSO), preparado a partir de soluções estoques em 100\% DMSO. Os controles negativos incluíram embriões expostos apenas ao meio E3 ou suplementado com 0,5\% DMSO. Camptotecina (CPT), um conhecido inibidor da proliferação celular, foi usado como controle positivo a uma concentração de $0,001 \mu \mathrm{M}$ em meio E3/0,5\% DMSO. Peixes-zebra adultos foram 
colocados para reprodução um dia antes da montagem experimental, em seguida, embriões viáveis foram coletados e selecionados para uso. Os experimentos foram realizados em triplicata, de acordo com as especificações da Organização para Cooperação e Desenvolvimento Econômico (OCDE). Um embrião/ poço (25 embriões por concentração) foi distribuído em microplacas de 96 poços na presença ou ausência dos compostos químicos. As placas foram mantidas em incubadoras BOD com temperatura controlada de $28,5^{\circ} \mathrm{C}$ e com fotoperíodo de $14 \mathrm{~h}$ claro: $10 \mathrm{~h}$ escuro. Após $24 \mathrm{~h}$, 48h, 72h e 96h, os embriões expostos foram avaliados de acordo com os seguintes parâmetros: mortalidade, presença de coagulação, taxa do batimento cardíaco, eclosão e presença de anormalidades morfológicas. Fotografias foram obtidas por fotomicroscopia. A apoptose foi avaliada pelo ensaio de DNA ladder. O DNA foi extraído pelo método fenol:clorofórmio e analisado por eletroforese em gel de agarose a 2\%. Fragmentos de DNA foram visualizadas após coloração com brometo de etídio em um transiluminador ultravioleta. $\mathrm{A} \mathrm{LC}_{50}$ determinada para o BPA foi $70 \mu \mathrm{M}$ após 24 horas, $72 \mu \mathrm{M}$ após 48 horas, $47 \mu \mathrm{M}$ após 72 horas e $31 \mu \mathrm{M}$ após exposição por 96 horas. O BPA induziu alterações morfológicas e fisiológicas como edema de saco vitelino e edema pericárdico, atraso no tempo ou inibição da eclosão, deformação da coluna vertebral, diminuição da taxa de batimentos cardíacos e mortalidade. Em conclusão, este estudo demonstrou que o BPA induziu grande número de malformações em embriões de peixe-zebra em concentrações acima de $25 \mu \mathrm{M}$, corroborando as preocupações atuais relacionadas a presença generalizada do BPA no ar, alimento e água usados pelos seres humanos bem como nos fluidos e tecidos corporais.

Palavras-chave: bisfenol, toxicidade, embriogênese.

\section{Introduction}

BPA was first described by Aleksandr P. Dianin in 1891 and synthesized by Thomas Zincke in 1905 (Jalal et al., 2018). After the discovery of this chemical, studies have revealed its ability to form crosslinks in the polymerization of polycarbonate plastic. Since then, BPA has been used in the manufacture of polycarbonate which began in the year 1957 in the United States. Later, it was reported the estrogenic properties of BPA, which are closely correlated with the presence of $\mathrm{OH}$ groups in the para position of its chemical structure (Dodds and Lawson, 1936; Sodré et al., 2007; Kusvuran and Yildirim, 2013). Polycarbonate is a transparent polymer that has high thermal and mechanical resistance, and this property made this plastic one of the most widely used compound in the world (Jalal et al., 2018). Among the uses of BPA is the manufacture of food packaging and containers, particularly in the production of epoxy resins used to coat preserved food cans.

The great concern in recent years has been the fact that BPA may leak or migrate to the food during packaging and there are several reports indicating that human and wildlife animals may suffer adverse effects from exposure to BPA (Goloubkova and Spritzer, 2000; Bernardo et al., 2015). This migration may occur over time as a result of temperature change or mechanical force, where plastic components such as monomers, additives, dyes, printing inks, varnishes and other components may affect the organoleptic properties of food, producing harmful effects if their levels exceed the toxicological values determined by specific legislation (Fasano et al., 2012; Paz Oliveira et al., 2017).

BPA is considered an endocrine disruptor due to the similarity of its molecule to the estradiol hormone, resulting in the ability to detrimentally interfere with the endocrine system. In fact, BPA may mimic endocrine hormones through its binding to estrogen receptors (ER), although only high dose exposure can affect the functions of natural ER ligands, such as estrogens (Gould et al.
1998). There are several reports demonstrating that BPA is also capable of modifying DNA structure by forming adducts and modulate gene expression, inducing carcinogenesis, or interfering with receptor binding processes in post-receptor events. In addition, BPA could alter the action of the endocrine system in glands such as thyroid, hypothalamus and pituitary gland, as well as to act on certain reproductive processes (Atkinson and Roy, 1995; Fasano et al., 2012; Bernardo et al.., 2015; Paz Oliveira et al., 2017). Also, there are data showing that exposure to BPA even in concentrations lower than that determined by the FDA (Food and Drug Administration) are capable of causing damage to living organisms (Podein et al., 2010; Bernardo et al., 2015),

The correct assessment of health toxicity of compounds depends on in vitro or in vivo studies employing animal models capable of accurately representing the putative effects caused by them. Thus, the zebrafish (Danio rerio) was first identified in the 1980s as a good alternative animal model for testing toxicity of different class of compounds. Due to the great similarity of their genome compared to humans, $70 \%$ of human genes have at least one zebrafish ortholog, they have been increasingly used as experimental animal model, in the area of neurodegenerative and other human genetic diseases as well as in toxicological studies (Howe et al., 2013).

BPA is considered an environmental pollutant, since residues can be found in the environment at different levels because of the way they are disposed of, and thus BPA can reach the soil and water (Bernardo et al., 2015; Paz Oliveira et al., 2017). Therefore, the need to better understand the effects of different concentrations of BPA in human and identify its mechanism of action herein we used zebrafish embryos as a model to study the toxicity of BPA during the development. Considering the similarity of zebrafish and human genome we can, at least in part, have a starting point to evaluate the risk of BPA for human health as well as to get information to help in the development of 
policies or guidelines aiming the safety and preservation of the ecosystem and its biodiversity.

\section{Material and Methods}

Bisphenol A (2,2-Bis (4-hydroxyphenyl); propane; 4,4'-Isopropylidene diphenol) and camptothecin were purchased from SIGMA-ALDRICH. Stock solutions of BPA were previously prepared in 100\% DMSO (Dimethysulfoxide) and used for dilutions in E3 medium in order to reach the desired BPA concentrations. In the toxicity assays, DMSO concentration was always $0.5 \%$, which is not toxic for zebrafish at this concentration. Adult zebrafish were supplied by LABFISH laboratory from Special Academic Unit of Biological Sciences from Federal University of Goiás, Jataí Branch, and maintained as previously described by Kimmel et al. (1995). Male and female fishes were placed for breeding a day before experiment, and then the embryos were collected and selected for viability. Only viable embryos were used. Three independent experiments were carried out, each one containing 20 embryos/concentration, according to specifications from Organization for Economic Cooperation and Development (OECD, 2013). BPA was used in concentrations of $1 \mu \mathrm{M}$, $2 \mu \mathrm{M}, 4 \mu \mathrm{M}, 8 \mu \mathrm{M}, 16 \mu \mathrm{M}, 25 \mu \mathrm{M}, 50 \mu \mathrm{M}, 60 \mu \mathrm{M}, 70 \mu \mathrm{M}, 80 \mu \mathrm{M}$, $90 \mu \mathrm{M}$ and $100 \mu \mathrm{M}$ in E3 medium/0.5\% DMSO. Negative controls included embryos exposed to E3 medium alone or supplemented with $0.5 \%$ DMSO. Positive controls included embryos exposed to camptothecin (CPT) at $0.001 \mu \mathrm{M}$ in E3 medium $/ 0.5 \%$ DMSO. CPT is a known inhibitor of the enzyme topoisomerase which is involved in DNA replication and repair. Ninety-six well microplates containing one embryo per well (20 embryos/concentration) exposed to BPA at different concentrations were kept in BOD incubator with a controlled temperature of $28.5^{\circ} \mathrm{C}$ and with photoperiod of $14 \mathrm{~h}$ light: $10 \mathrm{~h}$ dark. After $24 \mathrm{~h}, 48 \mathrm{~h}, 72 \mathrm{~h}$ and $96 \mathrm{~h}$ pos exposure, the plates were evaluated and embryos were analyzed for mortality, rate of heartbeat, hatching and presence of anomalies. Effect of BPA on the morphology of embryos were registered by using a photomicroscope. For the evaluation of apoptosis, we performed the DNA ladder assay. Briefly, DNA from a pool of 20 embryos exposed to different concentrations of BPA was extracted by standard phenol Chloroform: Alcohol isoamyl method, followed by electrophoresis analysis on $2 \%$ agarose gel stained by ethidium bromide. DNA bands were visualized on a transiluminator.

Statistical analyzes were performed using Graphpad prism software version 5.0. The normality test adopted were the Kolmogorov Smirnov and Shapiro wilk, where it was found that the analyzed values have normal distribution, and then the average for comparison between groups was used. In order to compare survival differences between groups of embryos exposed and non-exposed to BPA we used one-way ANOVA followed by the Tukey multiple comparison test. The methods used in this work have been approved by the ethics review committee from Federal University of Goiás under protocol number: 023/18.

\section{Results}

During an initial attempt to determine the range of BPA exhibiting toxicity to zebrafish embryos we observed that the concentrations ranging from $1 \mu \mathrm{M}$ to $16 \mu \mathrm{M}$ did not show any statistical diference in the survival and development of zebrafish compared to untreated controls for a period of 96 hours (data not shown). Also, concentrations of DMSO below $0.5 \%$ does not affect survival or morphology of embryos. Therefore, we tested the following concentrations $25 \mu \mathrm{M}, 50 \mu \mathrm{M}, 60 \mu \mathrm{M}, 70 \mu \mathrm{M} 80 \mu \mathrm{M}, 90 \mu \mathrm{M}$ e $100 \mu \mathrm{M}$ in a final concentration of $0.5 \%$ DMSO. Camptothecin, a known inhibitor of topoisomerase, an enzime involved in DNA replication and repair was used as positive control at a concentration of $0.001 \mu \mathrm{M}$.

Lethality of $50 \%\left(\mathrm{LC}_{50}\right)$ of zebrafish embryos could be observed at $70 \mu \mathrm{M}$ in the period of 24 hours of exposure. At this concentration, after 72 hours exposure, the rate of mortality increased to $90 \%$. Embryos exposed to concentrations of $25 \mu \mathrm{M}$ showed mortality rates similar to control group without treatment with BPA. The drug used as positive control, CPT, induced mortality rate of approximately $70 \%$ in the period of 24 hours of exposure reaching $100 \%$ of mortality at 96 hours of the experiment (see Figure 1). The BPA concentration able to induce 50\% mortality was calculated and determined as $70 \mu \mathrm{M}$ after 24 hours, $72 \mu \mathrm{M}$ after 48 hours, $47 \mu \mathrm{M}$ after 72 hours and $31 \mu \mathrm{M}$ after 96 hours of exposure.

The hatching rate of zebrafish embryos starts sporadically around $48 \mathrm{hpf}$ (hours post fertilization) (Kimmel et al., 1995). Compared to the control group, BPA concentration of $25 \mu \mathrm{M}$ induced a delay in the hatching period of approximately $40 \%$ of embryos at 72 hours exposure. At the same period control embryos showed $100 \%$ hatching. Additionally, no hatching was observed for the embryos exposed to BPA concentrations of $50 \mu \mathrm{M}$, $60 \mu \mathrm{M}$ and $70 \mu \mathrm{M}$ and over time these embryos died inside the chorionic membrane demonstrating a coagulation mass. Furthermore, at concentrations of $80 \mu \mathrm{M}, 90 \mu \mathrm{M}$ and $100 \mu \mathrm{M} 90 \%$ of mortality was observed 24 hours after exposure to BPA (see Figure 2).

Heartbeat rates of the embryos exposed to BPA was compared to the non-exposed controls in order to verify the hypothesis that the BPA interferes with cardiovascular development. In general, embryos from the control group presented an average of $84 \mathrm{bpm}$ at $24 \mathrm{hpf}, 116 \mathrm{bpm}$ at $48 \mathrm{hpf}$, $144 \mathrm{bpm}$ at $72 \mathrm{hpf}$ and $167 \mathrm{bpm}$ at $96 \mathrm{hpf}$. BPA decreases the heartbeat rate in a dose dependent manner and the effect is more pronounced at concentrations higher than $50 \mu \mathrm{M}$. As the concentrations of BPA increase, a marked decrease in heartbeat rate is observed until reaching a critical number of $7 \mathrm{bpm}$ at concentration of $50 \mu \mathrm{M}$ which will culminate with the death of the embryo up to 96 hours of exposure. The concentration of $25 \mu \mathrm{M}$ shows an average of $98 \mathrm{bpm}$ at $96 \mathrm{hpf}$. This heartbeat rate compared to $167 \mathrm{bpm}$ observed for the control group embryos at the same period, although lower, it is enough to allow the survival of approximately $60 \%$ of embryos for additional 

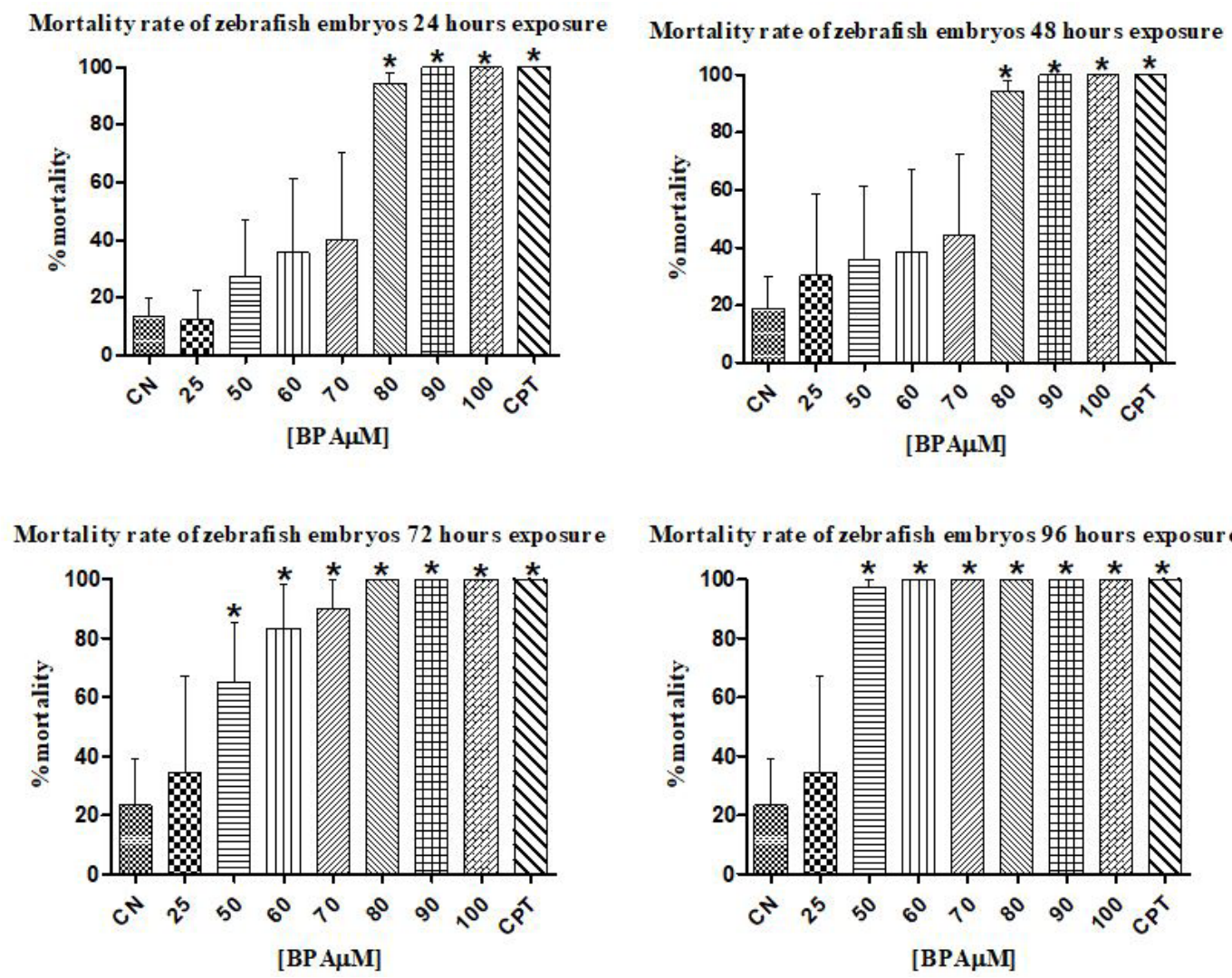

Figure 1. Effect of different concentrations of BPA on the mortality of zebrafish embryos exposed for 24 to 96 hours. Zebrafish embryos (25 per concentration) were distributed in 96 well microplates (one embryo/well) and exposed to BPA at concentrations ranging from 25 to $100 \mu \mathrm{M}$ in a final volume of $300 \mu 1$. Mortality was assessed after the time indicated. $\mathrm{CN}$-control without treatment, only vehicle DMSO $0.5 \%$. Figures represent the mean and standard deviation from triplicates. ${ }^{*}$ Statistically significant compared to control $\mathrm{p}<0.05$.

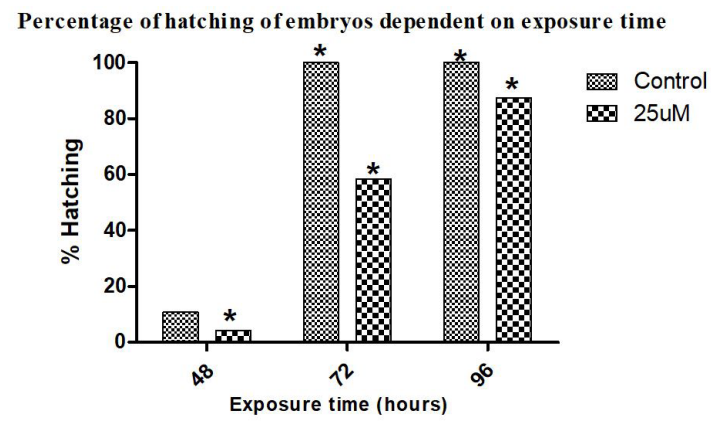

Figure 2. Decrease and delay of hatching rate of zebrafish embryos exposed to BPA for different periods of time.*Statistically significant compared to respective controls and $48 \mathrm{~h}$ exposure time $\mathrm{p}<0.05$.

time from the initial exposure (see Figure 1). However, analyzes of these surviving embryos for periods of $120 \mathrm{hpf}$ and $144 \mathrm{hpf}$ demonstrated the same effects seen with the highest concentrations of BPA culminating with the death of the embryo at the larvae stage (see Figure 3).

Regarding the morphophysiological aspects of the embryos exposed to BPA several alterations could be observed. BPA induced pericardial edema, yolk sac edema, malformations in spinal and / or head and shorter tail length. It was possible to observe that as earlier as $24 \mathrm{hpf} 50 \%$ of the embryos in the concentration of $70 \mu \mathrm{M}$ presented some type of morphological impairment preventing its survival up to $96 \mathrm{hpf}$. At the concentration of $80 \mu \mathrm{M}$ the few surviving embryos presented some type of developmental anomaly. Embryos exposed to concentrations of $25 \mu \mathrm{M}$ and $50 \mu \mathrm{M}$ presented similar effects, and the longer the exposure time, the greater the morphological abnormality observed (see Table 1).

The appearance of normal control embryos developed in medium without BPA is shown in Figure 4. In contrast, embryos exposed to different concentrations of BPA showed morphological changes and signs of toxicity, such as pericardial edema, yolk sac edema, body malformation, cell death and degradation (see Figure 5 and Figure 6).

One of the hallmarks of programmed cell death (apoptosis) is the chromatin condensation and DNA fragmentation, also known as internucleossomal fragmentation. In order to demonstrate DNA fragmentation, we tried to perform DNA ladder assay in zebrafish embryos exposed to BPA at different periods of time. 

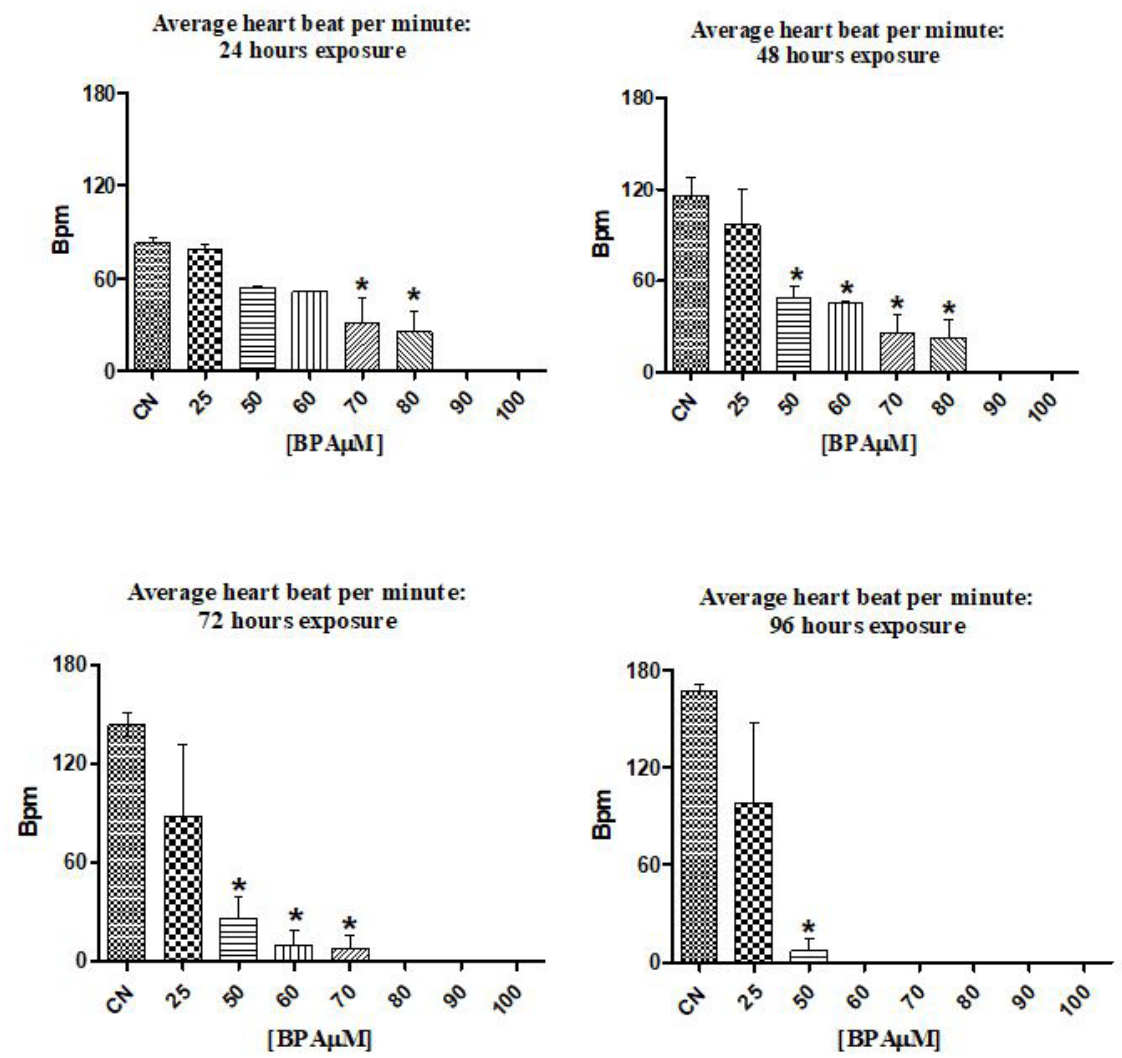

Figure 3. Decrease in the heartbeat rate of zebrafish embryos exposed to BPA at different concentrations for different periods of time. BPM - beats per minute.*Statistically significant compared to control $\mathrm{p}<0.05$.

Table 1. Percentage of zebrafish embryos showing morphophysiology abnormalities induced by BPA exposure.

\begin{tabular}{|c|c|c|c|c|}
\hline & \multicolumn{4}{|c|}{ Pericardial edema } \\
\hline & $24 h$ & $48 \mathrm{~h}$ & $72 \mathrm{~h}$ & 96h \\
\hline Control & $0 \%$ & $0 \%$ & $0 \%$ & $0 \%$ \\
\hline BPA $25 \mu \mathrm{M}$ & $0 \%$ & $0 \%$ & $4.2 \%$ & $4.2 \%$ \\
\hline BPA $50 \mu \mathrm{M}$ & $14.2 \%$ & $14.5 \%$ & $20.0 \%$ & $-{ }^{a}$ \\
\hline BPA $60 \mu \mathrm{M}$ & $18.4 \%$ & $20.0 \%$ & - & - \\
\hline BPA $70 \mu \mathrm{M}$ & $25 \%$ & $55 \%$ & - & - \\
\hline \multirow[t]{3}{*}{ BPA $80 \mu \mathrm{M}$} & $100 \%$ & - & - & - \\
\hline & \multicolumn{4}{|c|}{ Yolk sac edema } \\
\hline & $24 \mathrm{~h}$ & $48 h$ & $72 \mathrm{~h}$ & $96 \mathrm{~h}$ \\
\hline Control & $0 \%$ & $0 \%$ & $0 \%$ & $0 \%$ \\
\hline BPA $25 \mu \mathrm{M}$ & $0 \%$ & $0 \%$ & $4.5 \%$ & $4.5 \%$ \\
\hline BPA $50 \mu \mathrm{M}$ & $11.2 \%$ & $19.5 \%$ & $25.0 \%$ & - \\
\hline BPA $60 \mu \mathrm{M}$ & $13.4 \%$ & $18.0 \%$ & - & - \\
\hline BPA $70 \mu \mathrm{M}$ & $25 \%$ & $55 \%$ & - & - \\
\hline \multirow[t]{3}{*}{ BPA $80 \mu \mathrm{M}$} & $100 \%$ & - & - & - \\
\hline & \multicolumn{4}{|c|}{ Malformation of tail and spine } \\
\hline & $24 h$ & $48 \mathrm{~h}$ & $72 \mathrm{~h}$ & 96h \\
\hline Control & $0 \%$ & $0 \%$ & $0 \%$ & $0 \%$ \\
\hline BPA $25 \mu \mathrm{M}$ & $0 \%$ & $0 \%$ & $4.5 \%$ & $5.0 \%$ \\
\hline BPA $50 \mu \mathrm{M}$ & $20.0 \%$ & $24.5 \%$ & $24.5 \%$ & - \\
\hline BPA $60 \mu \mathrm{M}$ & $18.4 \%$ & $20.0 \%$ & - & - \\
\hline BPA $70 \mu \mathrm{M}$ & $25 \%$ & $55 \%$ & - & - \\
\hline BPA $80 \mu \mathrm{M}$ & $100 \%$ & - & - & - \\
\hline
\end{tabular}

a- Not determined. Death of embryos before analysis. 


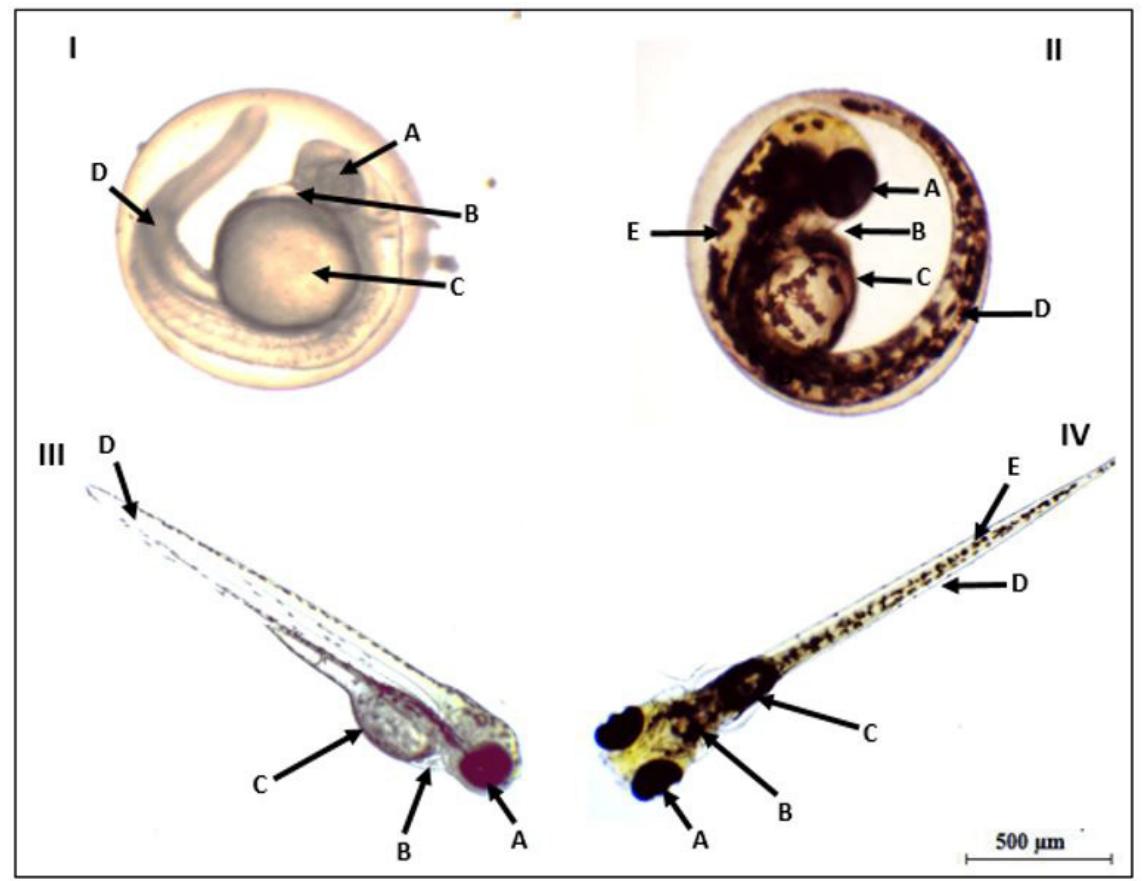

Figure 4. Early and late stages of zebrafish development. (I) 24 hpf embryo (II) 48 hfp embryo (III) 72 hpf larvae stage (IV) $96 \mathrm{hpf}$ larvae stage. Arrows indicate: (A) eyes (B) heart (C) yolk sac (D) tail and (E) early pigmentation.

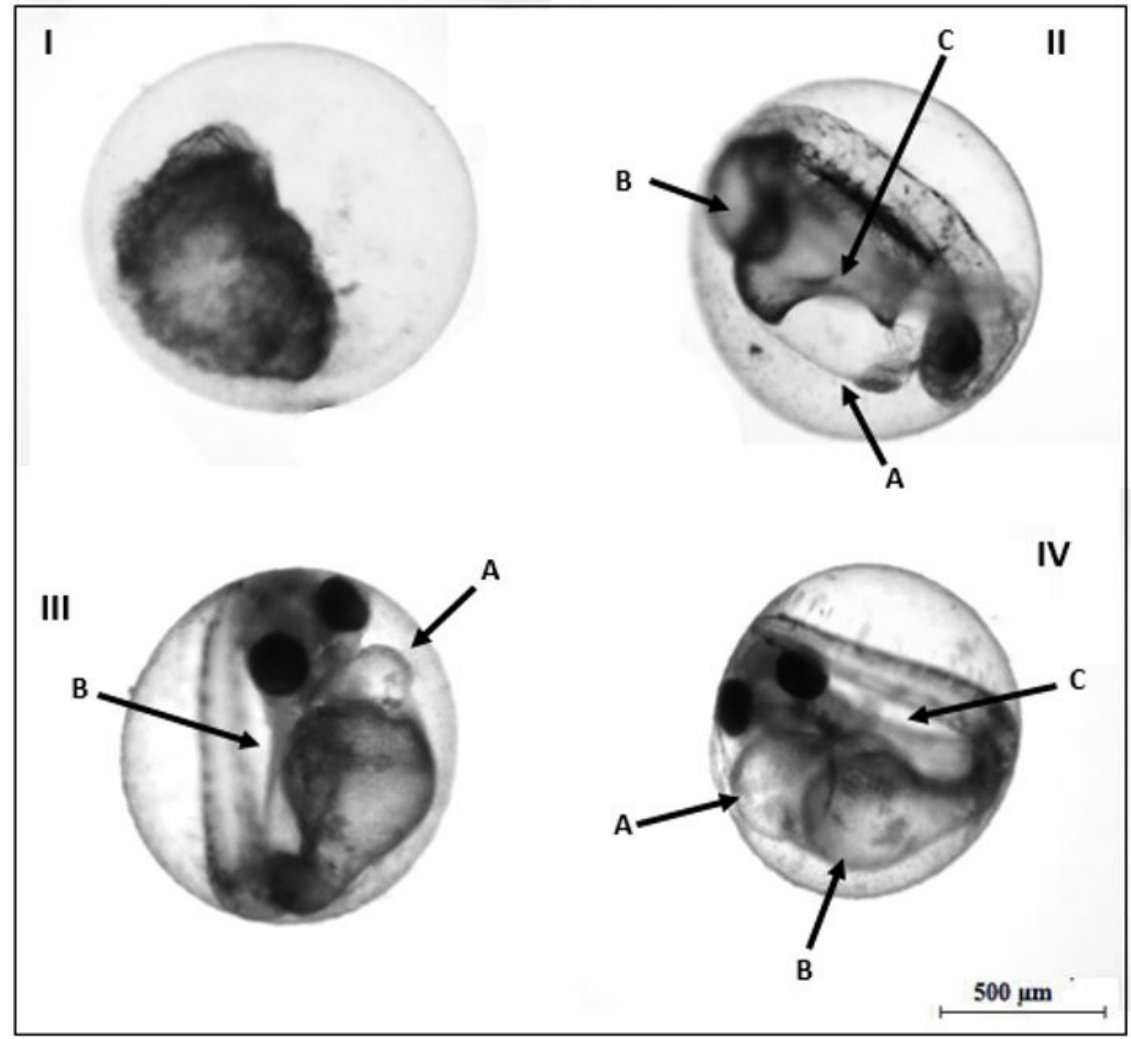

Figure 5. BPA induced malformation in zebrafish embryos. (I) Embryo coagulation (II) zebrafish embryo exposed to $70 \mu \mathrm{M}$ BPA after 48 hours. (III) Zebrafish embryo exposed to $50 \mu \mathrm{M}$ BPA after 72 hours (IV) Zebrafish embryo exposed to $60 \mu \mathrm{M}$ BPA after 96 hours. Arrows indicate: (A) Pericardial edema; (B) (II) No tail detachment (III) dorsal malformations (IV) yolk sac edema; (C) (II)Yolk sac edema (IV) dorsal malformations. 


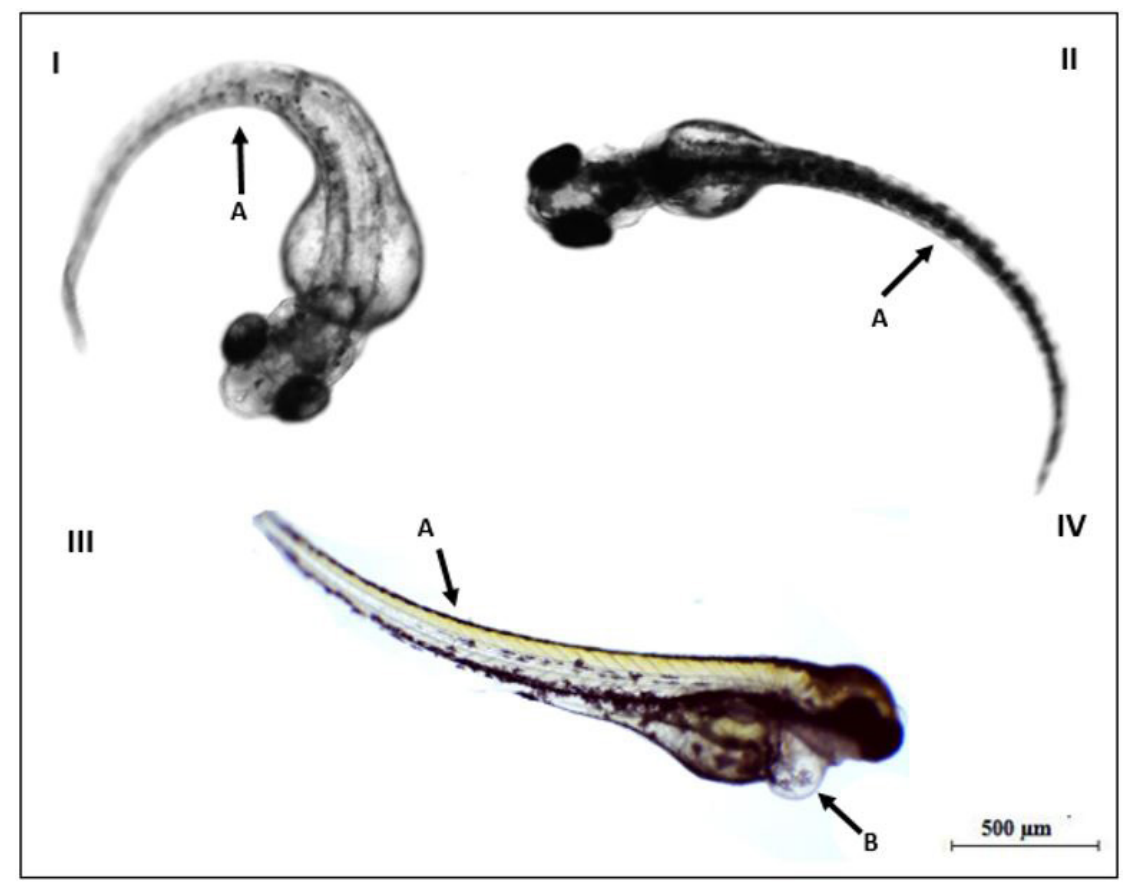

Figure 6. BPA induced malformation of zebrafish larvae. (I) Larvae hatched from zebrafish embryos exposed to 50 $\mu \mathrm{M}$ BPA for $72 \mathrm{~h}$. (II) Larvae hatched from zebrafish embryos exposed to $25 \mu \mathrm{M}$ BPA for $72 \mathrm{~h}$. (III) Larvae hatched from zebrafish embryos exposed $25 \mu \mathrm{M}$ BPA for $96 \mathrm{~h}$. Arrows indicate: (A) Dorsal malformations (B) Pericardial edema.

A
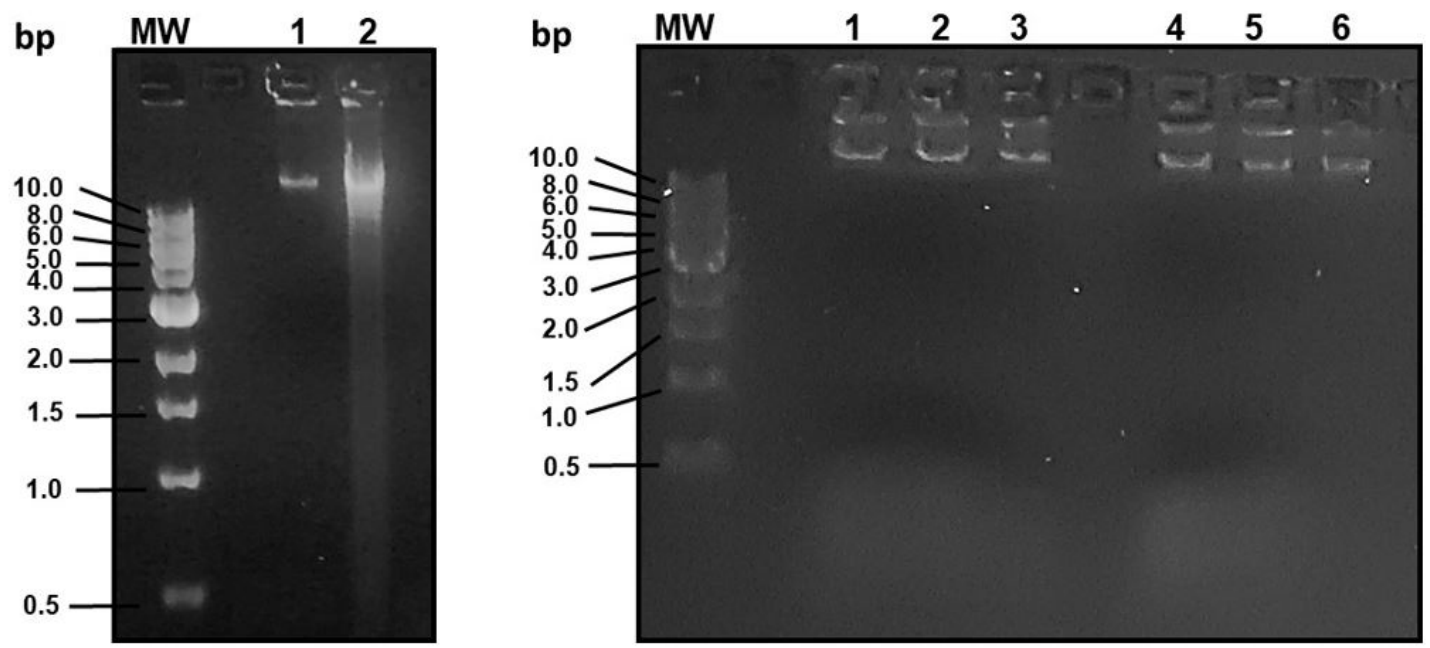

Figure 7. Absence of typical DNA ladder fragmentation in zebrafish embryos exposed to BPA. Approximately 20 embryos were exposed to CPT for 1 hour or BPA for 1,2,3 and 24 hours. Total DNA was extracted by phenol:chorophorm and loaded onto $2 \%$ agarose gel and electrophoresed. (A) 1) negative untreated control, 2) CPT treated embryos after 1 hour exposure. MW-molecular weight marker, bp - base pairs; (B) DNA from untreated negative controls (Lanes 1, 2 and 3) and BPA treated embryos (Lanes 4, 5 and 6) exposed for 1, 2 and 24 hours respectively.

However, the DNA laddering pattern, typical of apoptosis could not be observed in DNA extracted from embryos exposed to BPA. In contrast, embryos exposed to the positive control drug camptothecin, demonstrated the laddering at $1 \mathrm{~h}$ exposure (see Figure 7).

\section{Discussion}

Our results demonstrated an evident cytotoxicity of bisphenol A in zebrafish embryos. In fact, BPA concentrations higher than $70 \mu \mathrm{M}$ induced several toxic effects that 
culminate in the death of the embryos as earlier as 24 hours of exposure. Heart cells in normal embryos begin to contract and are visible under microscope as earlier as $24 \mathrm{hpf}$. This contraction demonstrate a coordination that is measurable of approximately $90 \mathrm{bpm}$ at this stage (Kimmel et al., 1995; Goloubkova and Spritzer, 2000; Paz Oliveira et al., 2017). We showed that embryos exposed to $50 \mu \mathrm{M}$ BPA have a significant decrease in heartbeat rate at $48 \mathrm{~h}$. At the concentration of $70 \mu \mathrm{M}$ and $80 \mu \mathrm{M}$ this decrease can be observed as earlier as 24 hours, when embryos presented an average of $31 \mathrm{bpm}$ and $25 \mathrm{bpm}$ respectively, compared to the untreated controls $(83 \mathrm{bpm})$ in the same period. Therefore, it becomes evident the toxicological effects of BPA in the cardiovascular system development. In addition, morphophysiological effects that may be associated with this condition such as a large increase in pericardial edema and yolk sac also could be observed.

A study conducted with zebrafish embryos at the concentration of $50 \mu \mathrm{M}$ BPA also demonstrated that early embryogenesis is affected by BPA exposure (Yang et al., 2015). Our results corroborate this study demonstrating similar toxic effects in the same concentration and showing that concentration of $100 \mu \mathrm{M}$ is highly toxic leading to the death of the embryos in $24 \mathrm{~h}$ after exposure.

The hatching rate of zebrafish embryos starts sporadically from 48 hpf to $72 \mathrm{hpf}$ (Kimmel et al., 1995). A study done by Canesi and Fabbri (2015) on the environmental effects of BPA on aquatic species reports lethality in different species including zebrafish larvae with an $\mathrm{LC}_{50}$ of $8.04 \mathrm{mg} / \mathrm{L}$ (approximately $35 \mu \mathrm{M}$ ) after 96 hours of exposure. Also, a reduction of approximately $50 \%$ in embryo hatching rate after 96 hours was observed at the concentration of $5.25 \mathrm{mg}$ /L of BPA (approximately $23 \mu \mathrm{M}$ ). Our results showed similarity at the concentration of $25 \mu \mathrm{M}$ in the period of 72 after exposure where $40 \%$ of larvae did not hatch compared to the control. However, at 96 exposure approximately $90 \%$ of the embryos had hatched at this lower concentration, demonstrating that BPA may cause a delay of hatching and this is probably due to interference in larvae motility. Consistent with this hypothesis is the finding that an analogous of BPA, the bisphenol $\mathrm{F}$, affect embryonic motor neuron development and is associated to spinal defect and spontaneous movement inhibition (Mu et al., 2019).

The effects attributed do BPA comes mainly from its similarity to estrogen molecules. It is known that estrogens are hormones that play an important role in mammalian reproduction by acting in conjugation with specific receptors to induce the expression of transcription factors that, in turn, regulates a variety of genes. As a xenoestrogen, BPA can disturb and disrupt several hormonals signaling pathways. We can speculate based on the results found here, that other animals, including humans, may be affected by exposure to bisphenol A. Chronical exposure to BPA can occur from canned foods or even from fresh foods or dental materials. Milk or eggs from animals bred in polluted areas or watered with contaminated water are also sources of BPA exposure and this should be a subject of great concern (Van Landuyt et al., 2011; Geens et al., 2012).

Also, BPA migration from different sources, such as laminate flooring, adhesives containing epoxi resins, paints and electronic equipments into dust has been demonstrated. Concentrations ranging from $8 \mu \mathrm{g}$ to $10 \mu \mathrm{g}$ per gram of dust have been detected (Hanaoka et al., 2002; Geens et al., 2012). In a cohort study done by Li et al. (2011), epidemiological evidence of adverse effect of BPA on human semen quality was shown. Increasing urine BPA level was statistically significantly associated with decrease sperm concentration, decreased total sperm count and decreased sperm motility.

In humans, BPA is metabolized in the liver via two pathways: Glucoronidation and sulfation (Yokota et al., 1999) and once metabolized by sulfation it is excreted via urinary tract. However, compared to humans, the main route of BPA exposure to fish is not the diet, but inhalation through the gills, and metabolism of BPA via this route is not as efficient as in the liver. Therefore, it is reasonable to think that BPA-contaminated water may produce more relevant estrogenic effects in fish. Waters from rivers contaminated with BPA has been reported in different locations with concentrations up to $517 \mathrm{ng} / \mathrm{L}\left(2 \times 10^{-3} \mu \mathrm{M}\right)$ in Rio Grande do Sul and São Paulo States in Brazil with considerable ecotoxicological risk (Peteffi et al., 2019).

Galloway et al. (2010), in their studies evaluated the excretion of BPA in 24-hour urine from Italian adult males and found that the highest exposure of BPA may be associated with endocrine changes in males, with an increase in serum testosterone, but the mechanisms of action of BPA in increasing serum testosterone have not yet been elucidated. A study evaluating the production of steroid hormone in ovarian cells of rats demonstrated that BPA exposure increased mRNA synthesis and production of testosterone (Zhou et al., 2008). Hunt et al. (2009) showed that daily oral dosing of BPA is capable of causing meiotic aneuploidy in rats and that approximately 40-70\% of sporadic miscarriages were linked to chromosomal abnormalities of the concept.

BPA has been shown to interferes in the reproduction of vertebrates, possibly inducing deregulation of epigenetic mechanisms. Marked effects on reproduction inhibition have been demonstrated, particularly affecting oocyte maturation, expression of apoptosis genes, where the effector-caspase 3 was upregulated at concentrations of BPA $5 \mu \mathrm{g} / \mathrm{L}(0.02 \mu \mathrm{M}), 10 \mu \mathrm{g} / \mathrm{L}(0.04 \mu \mathrm{M})$ and $20 \mu \mathrm{g} / \mathrm{L}(0.08 \mu \mathrm{M})$ and the tumor suppressor protein (p53) was overexpressed at the concentration of $5 \mu \mathrm{g} / \mathrm{L}$ (Santangeli et al., 2016).

Although the DNA ladder assay performed in our study did not show an evident pattern of DNA fragments typical of cells undergoing apoptosis, this effect of BPA can not be discarded. It is possible that since we analyzed DNA extracted from the whole embryo and not from specific tissues may have interfered with the visualization of the laddering pattern. On the other hand, other mechanism of cell death such as autophagy or necrose may be occurring. Interesting, we observed that some embryos may have 
developed mechanism of resistance to lower concentrations of BPA that allow them to continuing developing and survive longer than embryos exposed to higher concentrations of BPA. However, this is not true for $70 \%$ of embryos that died at 96 hours. This suggests a time-dependent effect of exposure at concentrations lower than $50 \mu \mathrm{M}$. However, at concentrations greater than $70 \mu \mathrm{M}$, BPA is highly toxic causing a lethality of $100 \%$ of embryos after 24 exposure.

Studies looking at molecular mechanisms of BPA have shown involvement of the MAP Kinase pathway with activation of mitogen-activated protein kinases (ERKs / MAPKs), induction of $\mathrm{Ca}++$ release from intracellular vesicles and high binding affinity of the GPR30 membrane-associated estrogen receptor (Podein et al., 2010; Tse et al., 2013). Furthermore, BPA at low doses is able to interfere with the nuclear estrogen-related receptor (ERR) $\gamma$, and at high concentrations is able to bind to androgenic (AR) receptors, thereby inhibiting androgenic action (Gavrieli et al., 1992; Gorski et al., 1997; Santangeli et al., 2016).

It has been suggested that BPA alternative analogues could be used to avoid the toxic effects of BPA however, as demonstrated by a study conducted in China using zebrafish as a model, even the bisphenol A analogues named bisphenol F (BPF) and bisphenol S (BPS) also exhibit estrogenic activity and induce toxic effects similar to those presented here. Interestingly, in that work they showed that BPA increases in vivo estrogenic activity by increasing the levels of Er $\alpha$ protein (alpha estrogen receptor), together with mRNA levels of other receptors such as esr1, esr2a, esr2b and vtg1 (Mu et al., 2018).

Furthermore, it has been hypothesized that bisphenol A may be able to exert its effects through several mechanisms of action, including epigenetic modifications. This is a relevant fact, since the adverse effects in our organism can remain undetectable until the appearance of diseases induced by this compound (Kimmel et al., 1995; Goloubkova and Spritzer, 2000; Bernardo et al., 2015; Paz Oliveira et al., 2017). Finally, the results shown here with zebrafish model clearly demonstrate the toxic effects of BPA and could be extrapolated to other vertebrates. They suggest a possible impact of this chemical on our health, so it is necessary to emphasize the importance of development of strict policies regarding the use and disposal of materials containing BPA. Although we have shown here the negative acute effects of BPA at higher concentrations than those reported in food, dust, air or other materials, it is important to consider the possible chronic effects of BPA exposure which we are subjected during our daily activities. This should be a concern not only for public health but also for the safety of our environment.

\section{Conclusion}

Bisphenol A has direct toxic effect on the embryonic development of zebrafish at concentrations higher than $25 \mu \mathrm{M}$, leading to morphophysiological changes, decreasing motility, delaying hatching rate, decreasing heart rate and ultimately, death of the embryos.

\section{References}

ATKINSON, A. and ROY, D., 1995. In-vivo DNA adduct formation by bisphenol A. Environmental and Molecular Mutagenesis, vol. 26, no. 1, pp. 60-66. http://dx.doi.org/10.1002/em.2850260109. PMid:7641708.

BERNARDO, P. E. M.; NAVAS, S. A.; TIECO, L.; MURATA, F.; ALCÂNTARA, M. R. S., 2015. Bisphenol A: review on its use in the food packaging, exposure and toxicity. Revista do Instituto Adolfo Lutz, vol. 74, no. 1, pp. 1-11.

CANESI, L. and FABBRI, E., 2015. Environmental effects of BPA: focus on aquatic species. Dose-response : a publication of International Hormesis Society, vol. 13, no. 3, pp. 1-14.

DODDS, E.C. and LAWSON, W., 1936. Synthetic estrogenic agents without the phenanthrene nucleus. Nature, vol. 137, no. 3476, pp. 996. http://dx.doi.org/10.1038/137996a0.

FASANO, E., BONO-BLAY, F., CIRILLO, T., MONTUORI, P. and LACORTE, S., 2012. Migration of phthalates, alkylphenols, bisphenol A and di (2-ethylhexyl) adipate from food packaging. Food Control, vol. 27, no. 1, pp. 132-138. http://dx.doi.org/10.1016/j. foodcont.2012.03.005

GALLOWAY, T., CIPELLI, R., GURALNIK, J., FERRUCCI, L., BANDINELLI, S., CORSI, A.M., MONEY, C., MCCORMACK, P. and MELZER, D., 2010. Daily bisphenol a excretion and associations with sex hormone concentrations: results from the InCHIANTI adult population study. Environmental Health Perspectives, vol. 118, no. 11, pp. 1603-1608. http://dx.doi. org/10.1289/ehp.1002367. PMid:20797929.

GAVRIELI, Y., SHERMAN, Y. and BEN-SASSON, S.A., 1992. Identification of Programmed Cell Death In Situ via Specific Labeling of Nuclear DNA Fragmentation. The Journal of Cell Biology, vol. 119, no. 3, pp. 493-501. http://dx.doi.org/10.1083/ jcb.119.3.493. PMid:1400587.

GEENS, T., AERTS, D., BERTHOT, C., BOURGUIGNON, J.-P., GOEYENS, L., LECOMTE, P., MAGHUIN-ROGISTER, G., PIRONNET, A.-M., PUSSEMIER, L., SCIPPO, M.-L., VAN LOCO, J. and COVACI, A., 2012. A review of dietary and nondietary exposure to bisphenol-A. Food and Chemical Toxicology, vol. 50, no. 10, pp. 3725-3740. http://dx.doi.org/10.1016/j. fct.2012.07.059. PMid:22889897.

GOLOUBKOVA, T. and SPRITZER, P.M., 2000. Xenoestrogênios: o exemplo do bisfenol-A. Arquivos Brasileiros de Endocrinologia \& Metabologia, vol. 44, no. 4, pp. 323-330. http://dx.doi.org/10.1590/ S0004-27302000000400008.

GORSKI, J., WENDELL, D., GREGG, D. and CHUN, T.Y., 1997. Estrogens and the genetic control of tumor growth. Progress in Clinical and Biological Research, vol. 396, pp. 233-243. PMid:9108601.

GOULD, J.C., LEONARD, L.S., MANESS, S.C., WAGNER, B.L., CONNER, K., ZACHAREWSKI, T., SAFE, S., MCDONNELL, D.P. and GAIDO, K.W., 1998. Bisphenol A interacts with the estrogen receptor alpha in a distinct manner from estradiol. Molecular and Cellular Endocrinology, vol. 142, no. 1-2, pp. 203-214. http://dx.doi.org/10.1016/S0303-7207(98)00084-7. PMid:9783916.

HANAOKA, T., KAWAMURA, N., HARA, K. and TSUGANE, S., 2002. Urinary bisphenol A and plasma hormone concentrations in male workers exposed to bisphenol A diglycidyl ether and mixed organic solvents. Occupational and Environmental Medicine, vol. 
59, no. 9, pp. 625-628. http://dx.doi.org/10.1136/oem.59.9.625. PMid:12205237.

HOWE, K., CLARK, M.D., TORROJA, C.F., TORRANCE, J., BERTHELOT, C., MUFFATO, M., COLLINS, J.E., HUMPHRAY, S., MCLAREN, K., MATTHEWS, L., MCLAREN, S., SEALY, I., CACCAMO, M., CHURCHER, C., SCOTT, C., BARRETT, J.C., KOCH, R., RAUCH, G.J., WHITE, S., CHOW, W., KILIAN, B., QUINTAIS, L.T., GUERRA-ASSUNÇÃO, J.A., ZHOU, Y., GU, Y., YEN, J., VOGEL, J.H., EYRE, T., REDMOND, S., BANERJEE, R., CHI, J., FU, B., LANGLEY, E., MAGUIRE, S.F., LAIRD, G.K., LLOYD, D., KENYON, E., DONALDSON, S., SEHRA, H., ALMEIDA-KING, J., LOVELAND, J., TREVANION, S., JONES, M., QUAIL, M., WILLEY, D., HUNT, A., BURTON, J., SIMS, S., MCLAY, K., PLUMB, B., DAVIS, J., CLEE, C., OLIVER, K., CLARK, R., RIDDLE, C., ELLIOT, D., THREADGOLD, G., HARDEN, G., WARE, D., BEGUM, S., MORTIMORE, B., KERRY, G., HEATH, P., PHILLIMORE, B., TRACEY, A., CORBY, N., DUNN, M., JOHNSON, C., WOOD, J., CLARK, S., PELAN, S., GRIFFITHS, G., SMITH, M., GLITHERO, R., HOWDEN, P., BARKER, N., LLOYD, C., STEVENS, C., HARLEY, J., HOLT, K., PANAGIOTIDIS, G., LOVELL, J., BEASLEY, H., HENDERSON, C., GORDON, D., AUGER, K., WRIGHT, D., COLLINS, J., RAISEN, C., DYER, L., LEUNG, K., ROBERTSON, L., AMBRIDGE, K., LEONGAMORNLERT, D., MCGUIRE, S., GILDERTHORP, R., GRIFFITHS, C., MANTHRAVADI, D., NICHOL, S., BARKER, G., WHITEHEAD, S., KAY, M., BROWN, J., MURNANE, C., GRAY, E., HUMPHRIES, M., SYCAMORE, N., BARKER, D., SAUNDERS, D., WALLIS, J., BABBAGE, A., HAMMOND, S., MASHREGHI-MOHAMMADI, M., BARR, L., MARTIN, S., WRAY, P., ELLINGTON, A., MATTHEWS, N., ELLWOOD, M., WOODMANSEY, R., CLARK, G., COOPER, J., TROMANS, A., GRAFHAM, D., SKUCE, C., PANDIAN, R., ANDREWS, R., HARRISON, E., KIMBERLEY, A., GARNETT, J., FOSKER, N., HALL, R., GARNER, P., KELLY, D., BIRD, C., PALMER, S., GEHRING, I., BERGER, A., DOOLEY, C.M., ERSAN-ÜRÜN, Z., ESER, C., GEIGER, H., GEISLER, M., KAROTKI, L., KIRN, A., KONANTZ, J., KONANTZ, M., OBERLÄNDER, M., RUDOLPH-GEIGER, S., TEUCKE, M., LANZ, C., RADDATZ, G., OSOEGAWA, K., ZHU, B., RAPP, A., WIDAA, S., LANGFORD, C., YANG, F., SCHUSTER, S.C., CARTER, N.P., HARROW, J., NING, Z., HERRERO, J., SEARLE, S.M., ENRIGHT, A., GEISLER, R., PLASTERK, R.H., LEE, C., WESTERFIELD, M., DE JONG, P.J., ZON, L.I., POSTLETHWAIT, J.H., NÜSSLEIN-VOLHARD, C., HUBBARD, T.J., ROEST CROLLIUS, H., ROGERS, J. and STEMPLE, D.L., 2013. The zebrafish reference genome sequence and its relationship to the human genome. Nature, vol. 496, no. 7446, pp. 498-503. http:// dx.doi.org/10.1038/nature12111. PMid:23594743.

HUNT, P.A., SUSIARJO, M., RUBIO, C. and HASSOLD, T.J., 2009. The Bisphenol A experience: a primer for the analysis of environmental effects on mammalian reproduction 1. Biology of Reproduction, vol. 81, no. 5, pp. 807-813. http://dx.doi.org/10.1095/ biolreprod.109.077008. PMid:19458313.

JALAL, N., SURENDRANATH, A.R., PATHAK, J.L., YU, S. and CHUNG, C.Y., 2018. Bisphenol A (BPA) the mighty and the mutagenic. Toxicology Reports, vol. 5, pp. 76-84. http://dx.doi. org/10.1016/j.toxrep.2017.12.013. PMid:29854579.

KIMMEL, C.B., BALLARD, W.W., KIMMEL, S.R., ULLMANN, B. and SCHILLING, T.F., 1995. Stages of embryonic development of the zebrafish. Developmental Dynamics, vol. 203, no. 3, pp. 253-310. http://dx.doi.org/10.1002/aja.1002030302. PMid:8589427.

KUSVURAN, E. and YILDIRIM, D., 2013. Degradation of bisphenol A by ozonation and determination of degradation intermediates by gas chromatography -mass spectrometry and liquid chromatography -mass spectrometry. Chemical Engineering Journal, vol. 220, pp. 6-14. http://dx.doi.org/10.1016/j.cej.2013.01.064.

LI, D. K., ZHOU, Z., MIAO, M., HE, Y., WANG, J., FERBER, J., HERRINTON, L. J., GAO, E. and YUAN, W., 2011. Urine bisphenol-A (BPA) level in relation to semen quality. Fertil Steril, vol. 95, no. 2, pp. 625-630. http://dx.doi.org/10.1016/j. fertnstert.2010.09.026.

MU, X., HUANG, Y., LI, X., LEI, Y., TENG, M., LI, X., WANG, C. and LI, Y., 2018. Developmental effects and estrogenicity of bisphenol A alternatives in a Zebrafish embryo model. Environmental Science \& Technology, vol. 52, no. 5, pp. 3222-3231. http://dx.doi. org/10.1021/acs.est.7b06255.

MU, X., LIU, J., YUAN, L., YANG, K., HUANG, Y., WANG, C., YANG, W., SHEN, G. and LI, Y., 2019. The mechanisms underlying the developmental effects of bisphenol $\mathrm{F}$ on zebrafish. Biomolecules, vol. 9, no. 8, pp. E307. http://dx.doi.org/10.3390/ biom9080307. PMid:31349731.

OECD, 2013. Test No. 236: Fish Embryo Acute Toxicity (FET) Test, OECD Guidelines for the Testing of Chemicals, Section 2, Paris: OECD Publishing. https://doi.org/10.1787/9789264203709-en.

PAZ OLIVEIRA, G.D.C., ARAÚJO, J.V.S., CONDE JUNIOR, A.M., and PALOMBIT, K., 2017. Bisfenol A: possíveis efeitos e danos ao organismo - revisão de literatura. Jornal Interdisciplinar de Biociências, vol. 2, no. 2, pp. 11-16. http://dx.doi.org/10.26694/ jibi.v2i2.5699.

PETEFFI, G.P., FLECK, J.D., KAEL, I.M., ROSA, D.C., ANTUNES, M.V. and LINDEN, R., 2019. Ecotoxicological risk assessment due to the presence of bisphenol A and caffeine in surface waters in the Sinos River Basin - Rio Grande do Sul - Brazil. Brazilian Journal of Biology $=$ Revista Brasileira de Biologia, vol. 79, no. 4, pp. 712-721. http://dx.doi.org/10.1590/1519-6984.189752. PMid:30427383.

PODEIN, R.J., HERNKE, M.T., FORTNEY, L.W. and RAKEL, D.P., 2010. Sustainability, synthetic chemicals, and human exposure. Explore (New York, N.Y.), vol. 6, no. 3, pp. 186-188. $\mathrm{http} / / / \mathrm{dx}$. doi.org/10.1016/j.explore.2010.03.010. PMid:20451154.

SANTANGELI, S., MARADONNA, F., GIOACCHI, G., COBELLIS, G., PICCINETTI, C.C., VALLE, L.D. and CARNEVALI, O., SANTANGELI, S., MARADONNA, F., GIOACCHINI, G., COBELliS, G., PICCINETTI, C.C., DALLA VALlE, L. and CARNEVALI, O., 2016. BPA-induced deregulation of epigenetic patterns : effects on female Zebrafish reproduction. Scientific Reports, vol. 6, no. 1, pp. 21982. http://dx.doi.org/10.1038/ srep21982. PMid:26911650.

SODRÉ, F.F., MONTAGNER, C.C., LOCATELLI, M.A.F. and JARDIM, W.F., 2007. Ocorrência de interferentes endócrinos e produtos farmacêuticos em águas superficiais da região de Campinas (SP, Brasil). Journal of the Brazilian Society of Ecotoxicology, vol. 2, no. 2, pp. 187-196. http://dx.doi.org/10.5132/jbse.2007.02.012.

TSE, W.K.F., YEUNG, B.H.Y., WAN, H.T. and WONG, C.K.C., 2013. Early embryogenesis in zebrafish is affected by bisphenol A exposure. Biology Open, vol. 2, no. 5, pp. 466-471. http://dx.doi. org/10.1242/bio.20134283. PMid:23789094.

VAN LANDUYT, K.L., NAWROT, T., GEEBELEN, B., DE MUNCK, J., SNAUWAERT, J., YOSHIHARA, K., SCHEERS, H., GODDERIS, L., HOET, P. and VAN MEERBEEK, B., 2011. How much do resin-based dental materials release? A metaanalytical approach. Dental Materials, vol. 27, no. 8, pp. 723-747. http://dx.doi.org/10.1016/j.dental.2011.05.001. PMid:21664675. 
YANG, M., QIU, W., CHEN, B., CHEN, J., LIU, S., WU, M. and WANG, K.J., 2015. The in vitro immune modulatory effect of bisphenol a on fish macrophages via estrogen receptor $\alpha$ and Nuclear Factor- $\mathrm{\kappa B}$ signaling. Environmental Science \& Technology, vol. 49, no. 3, pp. 1888-1895. http://dx.doi.org/10.1021/es505163v. PMid:25565130.

YOKOTA, H., IWANO, H., ENDO, M., KOBAYASHI, T., INOUE, H., IKUSHIRO, S. and YUASA, A., 1999. Glucuronidation of the environmental oestrogen bisphenol A by an isoform of
UDPglucuronosyltransferase, UGT2B1 in the rat liver. The Biochemical Journal, vol. 340, no. Pt 2, pp. 405-409. http:// dx.doi.org/10.1042/bj3400405. PMid:10333482.

ZHOU, W., LIU, J., LIAO, L., HAN, S. and LIU, J., 2008. Effect of bisphenol A on steroid hormone production in rat ovarian theca-interstitial and granulosa cells. Molecular and Cellular Endocrinology, vol. 283, no. 1-2, pp. 12-18. http://dx.doi. org/10.1016/j.mce.2007.10.010. PMid:18191889. 